Jurnal KBP

Volume 1 - No. 3, Desember 2013

\title{
ANALISIS PENGARUH RENTABILITAS TERHADAP HARGA SAHAM PERBANKAN DI BURSA EFEK INDONESIA
}

\author{
Afriyeni \\ AKBP Padang \\ (afriyeni.yen@gmail.com)
}

\begin{abstract}
This study aims to determine the effect of each component contained in profitability as ROA , ROE, ROA, and NPM on the price of bank shares listed on the Indonesia Stock Exchange. Object of this research is the price of bank shares listed on the Indonesia Stock Exchange. Statistical model used in this study is a multiple linear regression model. Hypothesis testing is done in two ways, namely $t$ statistical test (ttest) for the partial test and $F$ test (Tes $-F$ ) to examine the effect of study variables simultaneously. The results based on t-tests from 2008 to 2012 found that profitability consisting of ROA, ROE, ROA, and NPM significant effect on stock price movements studied banking. Based on the F-test results obtained the overall study, that earnings have a significant effect on stock prices in 2008, with a significance level of 0.107 and in 2012 with a significance level of 0.140, while in 2009, 2010, and 2011 earnings no significant effect on stock prices, where in 2009, with a significance level of 0.644 , in 2010 with a significance of 0.788 and in 2011 with a significance of 0.527 .
\end{abstract}

Keywords : Earnings, ROA, ROE, ROA, NPM banking share prices

\section{PENDAHULUAN}

Peran perbankan dalam

perekonomian Indonesia sangat berpengaruh signifikan. Hal ini dibuktikan dengan tumbuhnya usahausaha baru yang didukung oleh lembaga perbankan. Arti penting perbankan juga dapat dilihat dari meningkatnya jumlah kredit yang diberikan oleh perbankan kepada para pelaku usaha, mulai dari usaha mikro, kecil dan menengah yang sering dikenal dengan UMKM. Selain itu, perbankan memiliki posisi penting dalam perkembangan sebuah negara.

Pertumbuhan ekonomi suatu negara, dimana perbankan berperan di dalamnya, mengharuskan bank-bank tersebut memiliki tingkat kesehatan keuangan yang baik pula. Dengan keuangan yang baik, bank dapat menjalankan programnya menyehatkan perekonomian bangsa. Bank yang sehat secara keuangan akan mendapat apresiasi dari publik yang sangat tinggi. Dengan demikian, ketika bank tersebut menjual sahamnya di bursa efek, bank akan mendapat tanggapan positif dari calon pembeli sahamnya dan secara otomatis sahamnya akan dibeli oleh investor.

Banyak cara yang dapat dilakukan untuk mengukur tingkat kesehatan keuangan suatu bank. Dari beberapa cara, ada aspek-aspek yang perlu diperhatikan untuk menilai kinerja sebuah bank. Aspek-aspek tersebut dapat berupa analisis 
likuiditas, rentabilitas, dan solvabilitas. Ketiga analisis ini setidaknya sudah mencerminkan kinerja keuangan bank yang bersangkutan, dan untuk seorang investor hal yang perlu sangat diperhatikan yaitu analisis rentabilitas. Analisis ini akan sangat berpengaruh bagi investor dalam mengambil keputusan saham mana yang memberikan keuntungan baginya jika investor tersebut membeli saham sebuah bank di bursa efek.

Penilaian tentang kinerja perbankan tentunya memberikan dampak terhadap harga saham yang dikeluarkan pada setiap perusahaan perbankan. Saham merupakan salah satu instrumen pasar modal yang mendorong perkembangan pasar modal Indonesia. Seiring dengan perkembangan transaksi saham dalam pasar modal tersebut, kebutuhan informasi yang relevan dalam keputusan investasi perbankan di pasar modal juga meningkat. Analisis fundamental diperlukan untuk menentukan prospek perusahaan ke depan melalui analisis kinerja perbankan sebagai dasar memperoleh harga saham yang wajar.

Perbankan yang sahamnya telah terdaftar di bursa efek dinilai berdasarkan harga saham yang tercatat pada papan bursa. Harga saham dapat dikatakan sebuah indikator bagi investor maupun calon investor untuk melihat kinerja keuangan perbankan, di mana harga saham menentukan posisi sebuah bank di bursa. Harga saham bisa dikatakan sebagai indikator keberhasilan perusahaan jika kekuatan pasar di bursa ditunjukkan dengan adanya transaksi jual beli saham tersebut di pasar modal. Terjadinya transaksi tersebut berdasarkan atas analisa para investor terhadap prestasi perusahaan dalam meningkatkan keuntungan (Santoso, 1999:387).
Naik turunnya harga suatu saham dipengaruhi oleh beberapa faktor di mana faktor-faktor tersebut baik secara langsung maupun tidak langsung akan mempengaruhi terjadinya fluktuasi harga saham perusahaan. Adapun faktor-faktor yang berpengaruh terhadap harga saham dapat dibagi menjadi tiga kategori. Pertama faktor fundamental, merupakan faktor yang memberikan gambaran yang jelas yang bersifat analitis terhadap prestasi manajemen perusahaan dalam mengelola perusahaan yang menjadi tanggung jawabnya.

Kedua, faktor teknikal yang menyajikan informasi yang akan memberikan gambaran kepada investor dan calon investor untuk menentukan kapan pembelian saham dilakukan. Pada saat kapan saham tersebut dijual atau ditukar dengan saham yang lain agar dapat memperoleh keuntungan yang maksimal. Faktor ini meliputi tentang perkembangan nilai tukar uang, keadaan pasar modal, volume dan transaksi surat berharga serta kekuatan pasar modal dalam mempengaruhi harga saham perusahaan.

Ketiga adalah faktor yang bersifat sosial, ekonomi dan politik. Faktor ini secara tidak langsung berdampak terhadap harga suatu saham yang ada di bursa efek. Faktor-faktor tersebut di antaranya adalah tingkat inflasi yang terjadi, kebijakan moneter yang dikeluarkan oleh pemerintah, neraca pembayaran luar negeri, kondisi perekonomian nasional, keadaan politik suatu negara, stabilitas dari negara yang bersangkutan dan lain-lain.

Meskipun terdapat banyak faktor lain secara psikologis yang berpengaruh terhadap kekuatan pasar, tetapi faktor yang bersifat fundamental merupakan faktor yang menjadi pedoman utama bagi pasar untuk menentukan harga saham perusahaan. 
Bagi kalangan pebisnis terutama investor, yang menjadi hal penting untuk bisa mengetahui kondisi bidikan atau tujuan dari penempatan dana yang akan dilakukan adalah dengan mengetahui persis kondisi, stabilitas dan kontinuitas dari usaha tersebut. Kebutuhan akan informasi tersebut sebenarnya dapat dianalisis. Analisis yang dapat digunakan ada berbagai macam, di antaranya rasio keuangan. Analisis rasio keuangan yang terdiri dari, rasio likuiditas yaitu rasio yang mengukur kemampuan perusahaan dalam memenuhi kewajiban jangka pendeknya. Rasio solvabilitas (leverage) adalah rasio yang menyangkut penggunaan hutang. Rasio aktifitas adalah suatu bentuk pengukuran dari tingkat efektifitas pemanfaatan sumber daya perusahaan yang memberikan dampak bagi perusahaan. Rasio rentabilitas atau profitabilitas bermanfaat untuk menunjukkan keberhasilan perusahaan dalam menghasilkan keuntungan (Fahmi, 2006:55).

Analisis kinerja keuangan yang diukur dengan Return On Investment (ROI), Return On Equity (ROE), Operating Cash Flow (OCF) dan Economic Value Added (EVA) terhadap rate of return (studi pada perusahaan otomotif yang terdaftar di BEI) adalah penelitian yang telah diteliti oleh Prahesti (2009). Dalam penelitian ini menggunakan rasio keuangan ROI, ROE, OCF dan EVA. Penelitian ini menghasilkan kesimpulan bahwa variabel ROA dan OCF terbukti berpengaruh secara signifikan sedangkan variabel ROE dan EVA tidak berpengaruh secara signifikan.

Pemilihan saham perbankan sebagai objek penelitian disebabkan semakin banyaknya bank yang telah go public di Bursa Efek Indonesia, pergerakan harga saham-saham dari bank tersebut juga bergerak dinamis. Masuknya beberapa saham perbankan ke dalam kelompok saham-saham yang sangat likuid menempatkan saham perbankan tersebut menjadi saham dengan volume transaksi terbesar. Dengan demikian saham perbankan menjadi salah satu saham yang masuk dalam daftar investor untuk dipilih dan oleh karena itulah penulis sangat tertarik untuk melakukan penelitian terhadap saham perbankan dengan judul Pengaruh Rentabilitas terhadap Harga Saham Perbankan (Studi Kasus pada Bursa Efek Indonesia).

\section{TINJAUAN PUSTAKA DAN HIPOTESIS}

Pasar modal menurut Tandelilin (2001:26) adalah pertemuan antara pihak yang memiliki kelebihan dana dengan pihak yang membutuhkan dana dengan cara memperjualbelikan sekuritas. Dengan demikian, pasar modal juga bisa diartikan sebagai pasar untuk memperjualbelikan sekuritas yang umumnya memiliki umur lebih dari satu tahun, seperti saham dan obligasi. Sedangkan tempat di mana terjadinya jual-beli sekuritas disebut dengan bursa efek. Oleh karena itu, bursa efek merupakan arti dari pasar modal secara fisik. Untuk kasus di Indonesia terdapat satu bursa efek, yaitu Bursa Efek Indonesia (BEI). Sejak tahun 2007, Bursa Efek Jakarta (BEJ) dan Bursa Efek (BES) bergabung dan berubah nama menjadi Bursa Efek Indonesia.

Dana yang didapatkan perusahaan melalui penjualan sekuritas (saham) merupakan hasil perdagangan sahamsaham perusahaan yang dilakukan di pasar perdana. Di pasar perdana inilah perusahaan untuk pertama kalinya menjual sekuritasnya, dan proses itu disebut dengan istilah initial public offering (IPO) atau penawaran umum 
perdana. Setelah sekuritas tersebut dijual perusahaan di pasar perdana, barulah kemudian sekuritas diperjualbelikan oleh investor-investor di pasar sekunder atau dikenal juga dengan sebutan pasar reguler.

Harga saham menurut Halim (2005:12) adalah ringkasan dari pengaruh simultan dan kompleks dari berbagai macam variabel yang berpengaruh, terutama tentang kejadian-kejadian ekonomi bahkan kejadian politik, sosial dan keamanan karena saham merupakan bukti kepemilikan perusahaan yang berupa surat berharga atau efek yang diterbitkan oleh perusahaan yang terdaftar di bursa efek. Fluktuasi harga saham ditentukan oleh kemampuan perusahaan dalam memperoleh laba, apabila laba yang diperoleh perusahaan relatif tinggi maka akan berpengaruh positif terhadap harga saham di bursa, yang berakibat langsung pada permintaan dan diikuti oleh harga saham yang meningkat.

Menurut Undang-Undang No. 10 tahun 1998 Tentang Perubahan Undang-Undang No. 7 tahun 1992 Tentang Perbankan, pengertian bank adalah badan usaha yang menghimpun dana dari masyarakat dalam bentuk simpanan dan menyalurkan ke masyarakat dalam bentuk kredit dan atau bentuk-bentuk lainnya dalam rangka meningkatkan taraf hidup masyarakat banyak. Menurut undangundang tersebut jenis bank berdasarkan fungsinya terdiri dari Bank Umum dan Bank Perkreditan Rakyat (BPR)

Laporan keuangan pada dasarnya adalah hasil dari proses akuntansi yang dapat digunakan sebagai alat komunikasi antara data keuangan atau aktivitas suatu perusahaan dengan pihak-pihak yang berkepentingan dengan data atau aktivitas perusahaan tersebut. Menurut Munawir (2002,2), laporan keuangan adalah hasil dari proses akuntansi yang dapat digunakan sebagai alat berkomunikasi antara data keuangan atau aktifitas suatu perusahaan dengan pihak-pihak yang berkepentingan dengan data atau aktifitas perusahaan tersebut.

Analisis rasio keuangan adalah analisis dengan jalan membandingkan antara pos dengan pos laporan keuangan lainnya baik secara individu maupun bersama-sama guna mengetahui hubungan antara pos-pos tertentu baik dalam neraca maupun laba rugi (Abdullah, 2005:124).

Secara garis besar ada 3 rasio keuangan yang biasanya digunakan untuk menilai kinerja keuangan perusahaan yaitu, likuiditas, solvabilitas, dan rentabilitas. Adapun ketiga rasio tersebut dijelaskan sebagai berikut (Dendawijaya, 2004:114).

1) Analisis Rasio Likuiditas

Analisis yang dilakukan terhadap kemampuan bank dalam memenuhi kewajiban jangka pendeknya atau kewajiban yang sudah jatuh tempo. Beberapa rasio likuiditas yang sering dipergunakan dalam menilai kinerja suatu bank, antara lain adalah sebagai berikut:

a. Cash Ratio, cash ratio adalah alat likuid terhadap pihak ketiga yang dihimpun bank yang harus segera dibayar. Semakin tinggi rasio ini semakin tinggi pula kemampuan likuiditas bank yang bersangkutan.

b. Reserve Requirement, atau lebih dikenal dengan likuiditas wajib minimum, adalah suatu simpanan minimum yang wajib dipelihara dalam bentuk giro di Bank Indonesia bagi semua bank, berdasarkan surat edaran Bank Indonesia No. 23/17/13PPP tanggal 28 Februari 1992, besarnya reserve requirement $(\mathrm{RR})$ adalah 2\%. Terhitung sejak Februari 
1996, besarnya RR adalah 3\% dan sejak tahun 1997 menjadi 5\%. Alat likuid dalam rasio ini terdiri dari dua hal yaitu, kas dan giro pada Bank Indonesia, sedangkan komponen pihak ketiga terdiri atas, giro, deposito berjangka, sertifikat deposito, tabungan dan kewajiban jangka pendek lainnya.

c. Loan Deposite Ratio (LDR), rasio antara seluruh jumlah kredit yang diberikan bank dengan dana yang diterima oleh bank. Menurut surat edaran Bank Indonesia tanggal 29 Mei 1993, termasuk dalam pengertian dana yang diterima oleh bank adalah KLBI (kredit likuiditas Bank Indonesia) (jika ada), Giro, deposito, pinjaman masyarakat, Pinjaman bukan dari bank yang berjangka waktu lebih dari 3 bulan, tidak termasuk pinjaman sub ordinasi, Deposito dan pinjaman dari bank lain yang berjangka waktu lebih dari 3 bulan. Surat edaran yang diterbitkan oleh bank yang berjangka waktu lebih dari 3 bulan, Modal pinjaman. Modal inti.

d. Loan to assets ratio, rasio yang digunakan untuk mengukur tingkat likuiditas bank yang menunjukkan kemampuan bank untuk memenuhi permintaan kredit dengan menggunakan total aset yang dimiliki bank. Semakin tinggi rasio ini, tingkat likuiditasnya semakin kecil karena jumlah aset yang diperlukan untuk membiayai kreditnya menjadi semakin besar.

e. Rasio kewajiban bersih Call Money, presentase dari rasio ini menunjukkan besarnya kewajiban bersih call money terhadap aktiva lancar atau aktiva yang paling likuid dari bank jika rasio ini semakin kecil nilainya, likuiditas bank dinyatakan cukup baik karena bank dapat menutup segera kewajiban dalam kegiatan pasar uang antar bank dengan alat likuid yang dimilikinya. Aktiva lancar adalah berupa uang kas, giro pada BI, sertifikat Bank Indonesia dan surat berharga pasar uang (SBPU) yang telah di_endors oleh bank lain (kesemuanya dalam rupiah).

2) Analisis Rasio Solvabilitas

Analisis yang digunakan untuk mengukur kemampuan bank dalam memenuhi kewajiban jangka panjangnya atau kemampuan bank untuk memenuhi kewajiban-kewajiban jika terjadi likuidasi bank, di samping itu rasio ini digunakan untuk mengetahui perbandingan antara volume (jumlah) dana yang diperoleh dari berbagai utang (jangka pendek dan jangka panjang), serta sumber-sumber lain di luar modal bank sendiri, dengan volume penanaman dana tersebut pada berbagai jenis aktiva yang dimiliki bank. Beberapa rasio solvabilitas yaitu:

a) Capital Adequacy Ratio (CAR), adalah rasio kinerja bank untuk mengukur kecukupan modal yang dimiliki bank untuk menunjang aktiva yang mengandung atau menghasilkan resiko. $C A R$ merupakan indikator terhadap kemampuan bank untuk menutupi penurunan aktivanya sebagai akibat dari kerugian-kerugian bank yang disebabkan oleh aktiva-aktiva yang beresiko.

b) Debt to Equity Ratio, merupakan rasio yang digunakan untuk mengukur kemampuan bank dalam menutupi sebagian atau keseluruhan utang-utang jangka panjang maupun jangka pendeknya, dengan dana yang berasal dari modal bank itu sendiri, dengan kata lain rasio ini mengukur seberapa besar total passive yang terdiri dari presentase 
modal bank sendiri dibandingkan dengan besarnya utang.

c) Long Term Debt to Assets Ratio, rasio ini digunakan untuk mengukur seberapa jauh nilai suatu aktiva dibiayai atau dananya diperoleh dari sumber-sumber utang jangka panjang. Dalam bisnis perbankan, utang jangka panjang biasanya diperoleh dari simpanan masyarakat dengan jatuh tempo di atas satu tahun, dana pinjaman dari bank lain dalam rangka kerjasama antar bank, pinjamana luar negeri (biasanya dalam valuta asing), pinjaman dari Bank Indonesia serta pinjaman dari pemegang saham.

3) Analisis Rasio Rentabilitas

Alat untuk menganalisis atau mengukur tingkat efisiensi usaha atau profitabilitas yang dicapai oleh bank yang bersangkutan, dalam perhitungan rasio rentabilitas ini biasanya dicari hubungan timbal balik antar pos yang terdapat pada laporan laba rugi bank dengan pos-pos pada neraca bank guna memperoleh berbagai indikasi yang bermanfaat dalam mengukur tingkat efisiensi dan profitabilitas bank yang bersangkutan.

Analisis rasio rentabilitas, antara lain:

a. Return on Assets (ROA), rasio ini digunakan untuk mengukur kemampuan manajemen bank dalam memperoleh keuntungan secara keseluruhan, semakin besar return on assets suatu bank, semakin besar pula tingkat keuntungan yang dicapai bank tersebut dan semakin baik pula posisi bank tersebut dari segi penggunaan aset.

b. Return on Equity (ROE), ROE adalah perbandingan antara laba bersih bank dengan modal sendiri.
Rasio ini banyak diamati oleh para pemegang saham bank (baik pemegang saham pendiri maupun pemegang saham baru) serta para investor di pasar modal yang ingin membeli saham yang bersangkutan (jika bank tersebut telah Go Public).

c. Rasio Beban Operasional terhadap Pendapatan Operasional (BOPO), rasio ini merupakan perbandingan antara biaya operasional dan pendapatan operasional. Rasio operasional digunakan untuk mengukur tingkat efisiensi dan kemampuan bank dalam melakukan kegiatan operasinya.

d. Net Profit Margin (NPM) ratio, adalah merupakan rasio yang menggambarkan tingkat keuntungan yang diperoleh bank dibandingkan pendapatan yang telah diterima dari kegiatan operasionalnya. Sebagaimana perhitungan rasio-rasio sebelumnya, rasio NPM juga mengacu pada pendapatan operasional bank yang terutama berasal dari kegiatan pemberian kredit yang prakteknya memiliki berbagai resiko, seperti resiko kredit (kredit bermasalah dan kredit macet), bunga (negative spread), kurs valas (jika kredit diberikan dalam valas), dan lain-lain.

Beberapa penelitian terdahulu telah membahas hal-hal yang saling berkaitan yaitu, penelitian yang dilakukan oleh Astika (2004), tentang analisa kinerja keuangan bank BCA sebelum dan sesudah go public, penelitian ini menemukan kinerja keuangan berpengaruh dengan adanya peningkatan jumlah nilai bersih rasio CAMEL sebelum go public dengan sesudah go public. Penelitian berikutnya dilakukan oleh Kurniawati 
(2009), yang meneliti tentang rasio rentabilitas dan solvabilitas pada bank BRI, penelitian ini menghasilkan bahwa rasio rentabilitas berpengaruh signifikan dibandingkan dengan rasio solvabilitas. Penelitian ketiga yang masih ada relevansinya terhadap penelitian ini, yaitu yang dilakukan oleh Ari P. (2009) yang meneliti tentang pengaruh ROI, ROE, OCF dan EVA terhadap rate of return perusahaan otomotif yang terdaftar di bursa, dengan hasil penelitian menunjukkan variabel ROE dan OCF berpengaruh signifikan terhadap rate of return sedangkan variabel ROI dan EVA tidak berpengaruh signifikan.

Rojihah (2005) juga meneliti tentang pengaruh kinerja keuangan perbankan terhadap harga saham setelah IPO, penelitian tersebut menghasilkan bahwa variabel PER berpengaruh signifikan terhadap harga saham. Penelitian selanjutnya yang masih berkaitan dengan penelitian yang akan dilakukan, Santoso (2003) meneliti tentang variabel fundamental yang berpengaruh terhadap harga saham perbankan, menghasilkan adanya hubungan positif antara variabel ROA dengan harga saham dan terdapat hubungan negatif terhadap variabel credit risk, CAR dan EPS.

Hipotesis penelitian dapat dirumuskan sebagai berikut:

Ho: Diduga bahwa ROA, ROE, BOPO dan NPM tidak berpengaruh signifikan terhadap harga saham perbankan Bursa Efek Indonesia.

$\mathbf{H}_{1}$ : Diduga bahwa ROA berpengaruh signifikan terhadap harga saham perbankan Bursa Efek Indonesia.

$\mathbf{H}_{2}$ : Diduga bahwa ROE berpengaruh signifikan terhadap harga saham perbankan Bursa Efek Indonesia.
H3: Diduga bahwa BOPO berpengaruh signifikan terhadap harga saham perbankan Bursa Efek Indonesia.

H4 : Diduga bahwa NPM berpengaruh signifikan terhadap harga saham perbankan Bursa Efek Indonesia.

H5 : Diduga bahwa ROA, ROE, BOPO dan NPM secara bersama-sama berpengaruh signifikan terhadap harga saham perbankan Bursa Efek Indonesia.

\section{METODE PENELITIAN}

Objek penelitian ini adalah harga saham perbankan yang terdaftar di Bursa Efek Indonesia. Penelitian ini dilakukan untuk memberikan gambaran tentang bagaimana menganalisis pengaruh rasio rentabilitas terhadap harga saham perbankan periode 20082012. Teknik pengambilan sampel dalam penelitian ini dilakukan dengan metode purposive sampling, yaitu pengambilan sampel yang dipilih berdasarkan tujuan dan pertimbangan tertentu, misalnya alasan keterbatasan waktu, tenaga dan dana, sehingga tidak dapat mengambil sampel yang besar dan jauh, Arikunto (2006:139-140). Berdasarkan populasi yang ada, diambil sampel yang memenuhi kriteria sebagai berikut:

1) Terdaftar di Bursa Efek Indonesia dan perusahaan perbankan yang memiliki aset lebih dari $\mathrm{Rp} 50$ triliun.

2) Aktif memberikan laporan keuangan tahunan secara periodik kepada Bursa Efek Indonesia dengan lengkap tahun 2008 - 2012.

3) Bergerak dalam kelompok industri yang sama yaitu perbankan.

Berdasarkan daftar emiten yang aktif dan mempunyai data laporan keuangan yang lengkap selama periode penelitian diambil enam bank yang memiliki aset paling besar, seperti 
bank-bank yang terdapat pada tabel $1 . \quad$ berikut.

Tabel 1.

Daftar bank yang menjadi sampel penelitian

\begin{tabular}{|c|c|l|}
\hline No & Kode & \multicolumn{1}{|c|}{ Emiten } \\
\hline 1 & BMRI & PT. Bank Mandiri, Tbk \\
\hline 2 & BBRI & PT. Bank Rakyat Indonesia, Tbk \\
\hline 3 & BBCA & PT. Bank Central Asia, Tbk \\
\hline 4 & BBNI & PT. Bank Negara Indonesia, Tbk \\
\hline 5 & BNGA & PT. Bank CIMB Niaga, Tbk \\
\hline 6 & BDMN & PT. Bank Danamon Indonesia, Tbk \\
\hline
\end{tabular}

Sumber: Data sekunder diolah

Dalam penelitian ini terdapat 10 perusahaan dengan aset lebih dari Rp 50 triliun, dan dari 10 perusahaan tersebut, yang dijadikan sampel penelitian yaitu enam bank yang memiliki aset terbesar yang memenuhi kriteria pengambilan sampel berdasarkan metode purposive sampling seperti yang terdapat pada tabel 1. Data yang digunakan berupa laporan keuangan dan harga saham penutupan periode 2008, 2009, 2010, 2011 dan 2012, yang diterbitkan oleh Bursa Efek Indonesia.

\section{Variabel Terikat (Dependent)}

Variabel terikat dalam penelitian ini adalah harga saham yang dilihat dari harga penutupan pada akhir periode laporan keuangan per bulan tiap bank dalam IDX statistik tahun 2008-2012, harga penutupan adalah harga (rupiah) yang terjadi pada saham akibat adanya permintaan dan penawaran di pasar, yang ditentukan menjelang penutupan perdagangan di bursa setiap harinya. Karena perdagangan dilakukan setiap hari, maka harga penutupan saham bulanan adalah rata-rata harga yang terjadi pada suatu saham pada bulan tertentu.

Variabel Bebas (Independent)
Variabel bebas dalam penelitian ini adalah:

a. $\mathrm{X}_{1}$, Return on Assets (ROA), rasio yang digunakan untuk mengukur

kemampuan manajemen bank dalam memperoleh keuntungan secara keseluruhan, semakin besar ROA suatu bank, semakin besar pula tingkat keuntungan yang dicapai bank tersebut dari segi penggunaan aset, rasio ini dapat dirumuskan sebagai berikut:

$$
\text { ROA }=\frac{\text { Laba bersih }}{\text { Total Aktiva }} \times 100 \%
$$

b. $\mathrm{X}_{2}$, Return on Equity (ROE), adalah perbandingan antara laba bersih bank dengan modal sendiri, rasio ini dapat dirumuskan sebagai berikut:

$$
R O E=\frac{\text { Laba bersih }}{\text { Modal Sendiri }} \quad \mathrm{X} 100 \%
$$

c. $\mathrm{X}_{3}$, Beban Operasional terhadap Pendapatan Operasional (BOPO), rasio ini merupakan perbandingan antara biaya operasional dengan pendapatan operasional, rasio ini dapat dirumuskan sebagai berikut:

$$
B O P O=\frac{\text { Beban Operasional }}{\text { Pendapatan Operasional }} \times 100 \%
$$


d. $\mathrm{X}_{4}$, Net Profit Margin (NPM), adalah rasio yang menggambarkan tingkat keuntungan yang diperoleh bank dibandingkan pendapatan yang telah diterima dari kegiatan operasionalnya, rasio ini dapat dirumuskan sebagai berikut:

$$
\text { NPM }=\frac{\text { Laba Bersih }}{\text { Pendapatan Operasional }} \times 100 \%
$$

\section{Perumusan Model}

Model statistik yang digunakan dalam penelitian ini adalah model regresi linier berganda. Model analisis ini dipilih karena penelitian ini dirancang untuk meneliti pengaruh dari variabel bebas terhadap variabel terikat. Adapun rumusan model regresi linear berganda tersebut adalah:

$$
\mathrm{Y}=\mathrm{a}+\mathrm{b}_{1} \mathrm{X}_{1}+\mathrm{b}_{2} \mathrm{X}_{2}+\mathrm{b}_{3} \mathrm{X}_{3}+\mathrm{b}_{4} \mathrm{X}_{4}
$$

Pengujian hipotesis dilakukan dengan dua cara, yaitu uji statistik $t$ $(\mathrm{Uji}-\mathrm{t})$ untuk pengujian pengaruh secara parsial dan uji statistik F (Uji F) untuk menguji pengaruh secara simultan.

\section{HASIL DAN PEMBAHASAN Analisis Regresi Linier Berganda}

Berikut ini dapat dijelaskan analisis regresi dari masing-masing variabel setiap tahun:

1. Tahun 2008

Tabel 2. Koefisien Tahun 2008

Coefficients $^{\mathrm{a}, \mathrm{b}}$

\begin{tabular}{|ll|c|c|c|c|c|}
\hline \multirow{2}{*}{} & \multicolumn{5}{|c|}{ Model } \\
\cline { 3 - 7 } & \multicolumn{5}{|c|}{1} \\
\cline { 3 - 7 } & & (Constant) & ROA & ROE & BOPO & NPM \\
\hline Unstandardized Coefficients & B & 5,421 & 1,883 & $-0,160$ & $-0,024$ & $-0,129$ \\
& Std. Error & 0,184 & 0,186 & 0,019 & 0,002 & 0,014 \\
Standardized Coefficients & Beta & & 6,065 & $-3,525$ & $-0,894$ & $-2,423$ \\
T & & 29,498 & 10,124 & $-8,643$ & $-10,487$ & $-9,034$ \\
Sig. & & 0,022 & 0,063 & 0,073 & 0,061 & 0,070 \\
Correlations & Zero-order & & 0,389 & 0,258 & $-0,532$ & 0,385 \\
& Partial & & 0,995 & $-0,993$ & $-0,995$ & $-0,994$ \\
& Part & & 0,721 & $-0,615$ & $-0,747$ & $-0,643$ \\
Collinearity Statistics & Tolerance & & 0,014 & 0,030 & 0,697 & 0,070 \\
& VIF & & 70,815 & 32,817 & 1,435 & 14,192 \\
\hline
\end{tabular}

a. Tahun $=2008$

b. Dependent Variable: Harga Saham

Sumber: Data diolah

Berdasarkan hasil analisa regresi berganda yang disajikan pada tabel 2, tahun 2008, maka persamaan regresi bergandanya sebagai berikut:

$$
\begin{aligned}
\mathrm{Y}= & 5,421+1,883 \mathrm{X}_{1}-0,160 \mathrm{X}_{2}- \\
& 0,024 \mathrm{X}_{3}-0,129 \mathrm{X}_{4}
\end{aligned}
$$

$\begin{array}{ll}\text { Model persamaan regresi } \\ \text { berganda } & \text { tersebut dapat } \\ \text { diinterpretasikan sebagai berikut: }\end{array}$

a) Return On Assets (ROA) berpengaruh positif terhadap harga saham perbankan yang listed di
Bursa Efek Indonesia tahun 2008 dengan nilai koefisien berpengaruh

sebesar 1,883. Apabila terjadi peningkatan variabel ROA $1 \%$

dengan asumsi variabel lain tetap, maka akan berdampak terjadinya peningkatan harga saham sebesar $1,883 \%$. Berarti setiap $1 \%$ kenaikan ROA akan mengakibatkan terjadinya kenaikan harga saham sebesar 1,883\%. 
b) Return On Equity (ROE) berpengaruh negatif terhadap harga saham perbankan yang listed di Bursa Efek Indonesia tahun 2008 dengan nilai koefisien berpengaruh sebesar -0,160. Apabila terjadi peningkatan variabel ROE $1 \%$ dengan asumsi variabel lain tetap, maka akan berdampak terjadinya penurunan harga saham sebesar $0,160 \%$. Berarti setiap $1 \%$ kenaikan ROE akan mengakibatkan terjadinya penurunan harga saham sebesar $0,160 \%$.

c) Biaya Operasional terhadap Pendapatan Operasional (BOPO) berpengaruh negatif terhadap harga saham perbankan yang listed di Bursa Efek Indonesia tahun 2008 dengan nilai koefisien berpengaruh sebesar -0,024. Apabila terjadi peningkatan variabel BOPO $1 \%$ dengan asumsi variabel lain tetap, maka akan berdampak terjadinya penurunan harga saham sebesar $0,024 \%$. Berarti setiap $1 \%$ kenaikan BOPO akan mengakibatkan terjadinya penurunan harga saham sebesar $0,024 \%$.

d) Net Profit Margin (NPM) berpengaruh negatif terhadap harga saham perbankan yang listed di Bursa Efek Indonesia tahun 2008 dengan nilai koefisien berpengaruh sebesar -0,129. Apabila terjadi peningkatan variabel NPM $1 \%$ dengan asumsi variabel lain tetap, maka akan berdampak terjadinya penurunan harga saham sebesar $0,129 \%$. Berarti setiap $1 \%$ kenaikan NPM akan mengakibatkan terjadinya penurunan harga saham sebesar $0,129 \%$.

2. Tahun 2009

Tabel 3. Koefisien Tahun 2009

\begin{tabular}{|c|c|c|c|c|c|c|}
\hline \multicolumn{7}{|c|}{ Coefficients ${ }^{\mathrm{a}, \mathrm{b}}$} \\
\hline & & \multicolumn{5}{|c|}{ Model } \\
\hline & & \multicolumn{5}{|c|}{1} \\
\hline & & (Constant) & ROA & ROE & BOPO & NPM \\
\hline \multirow[t]{2}{*}{ Unstandardized Coefficients } & B & 5,042 & 0,649 & $-0,088$ & $-0,028$ & 0,025 \\
\hline & Std. Error & 1,670 & 0,774 & 0,138 & 0,020 & 0,052 \\
\hline Standardized Coefficients & Beta & & 2,177 & $-1,898$ & $-0,971$ & 0,480 \\
\hline $\mathrm{T}$ & & 3,019 & 0,839 & $-0,633$ & $-1,404$ & 0,478 \\
\hline Sig. & & 0,204 & 0,556 & 0,641 & 0,394 & 0,716 \\
\hline \multirow[t]{3}{*}{ Correlations } & Zero-order & & 0,514 & 0,583 & $-0,530$ & 0,537 \\
\hline & Partial & & 0,643 & $-0,535$ & $-0,815$ & 0,431 \\
\hline & Part & & 0,388 & $-0,293$ & $-0,649$ & 0,221 \\
\hline \multirow[t]{2}{*}{ Collinearity Statistics } & Tolerance & & 0,032 & 0,024 & 0,447 & 0,212 \\
\hline & VIF & & 31,477 & 42,047 & 2,238 & 4,718 \\
\hline
\end{tabular}

a. Tahun $=2009$

b. Dependent Variable: Harga Saham

Sumber: Data diolah

Berdasarkan hasil analisa regresi berganda yang disajikan pada tabel 3 tahun 2009, maka persamaan regresi bergandanya sebagai berikut:

$$
\begin{aligned}
\mathrm{Y}= & 5,042+0,649 \mathrm{X}_{1}-0,088 \mathrm{X}_{2}- \\
& 0,028 \mathrm{X}_{3}+0,025 \mathrm{X}_{4}
\end{aligned}
$$

Model persamaan regresi berganda tersebut dapat diinterpretasikan sebagai berikut:

a) Return On Assets (ROA) berpengaruh positif terhadap harga 
saham perbankan yang listed di Bursa Efek Indonesia tahun 2009 dengan nilai koefisien berpengaruh sebesar 0,649. Apabila terjadi peningkatan variabel ROA $1 \%$ dengan asumsi variabel lain tetap, maka akan berdampak terjadinya peningkatan harga saham sebesar $0,649 \%$. Berarti setiap $1 \%$ kenaikan ROA akan mengakibatkan terjadinya kenaikan harga saham sebesar 0,649\%.

b) Return On Equity (ROE) berpengaruh negatif terhadap harga saham perbankan yang listed di Bursa Efek Indonesia tahun 2009 dengan nilai koefisien berpengaruh sebesar -0,088. Apabila terjadi peningkatan variabel ROE $1 \%$ dengan asumsi variabel lain tetap, maka akan berdampak terjadinya penurunan harga saham sebesar $0,088 \%$. Berarti setiap $1 \%$ kenaikan ROE akan mengakibatkan terjadinya penurunan harga saham sebesar $0,088 \%$.

c) Biaya Operasional terhadap Pendapatan Operasional (BOPO) berpengaruh negatif terhadap harga saham perbankan yang listed di Bursa Efek Indonesia tahun 2009 dengan nilai koefisien berpengaruh sebesar -0,028. Apabila terjadi peningkatan variabel BOPO $1 \%$ dengan asumsi variabel lain tetap, maka akan berdampak terjadinya penurunan harga saham sebesar $0,028 \%$. Berarti setiap $1 \%$ kenaikan BOPO akan mengakibatkan terjadinya penurunan harga saham sebesar $0,028 \%$.

d) Net Profit Margin (NPM) berpengaruh positif terhadap harga saham perbankan yang listed di Bursa Efek Indonesia tahun 2009 dengan nilai koefisien berpengaruh sebesar 0,025. Apabila terjadi peningkatan variabel NPM $1 \%$ dengan asumsi variabel lain tetap, maka akan berdampak terjadinya kenaikan harga saham sebesar $0,025 \%$. Berarti setiap $1 \%$ kenaikan NPM akan mengakibatkan terjadinya kenaikan harga saham sebesar $0,025 \%$.

3. Tahun 2010

Tabel 4. Koefisien Tahun 2010

Coefficients $^{\mathrm{a}, \mathrm{b}}$

\begin{tabular}{|ll|c|c|c|c|c|}
\hline \multirow{2}{*}{} & \multicolumn{6}{|c|}{ Model } \\
\cline { 3 - 7 } & & \multicolumn{5}{|c|}{1} \\
\cline { 3 - 7 } & (Constant) & ROA & ROE & BOPO & NPM \\
\hline Unstandardized Coefficients & B & 2,910 & $-0,177$ & 0,067 & $-0,002$ & $-0,028$ \\
& Std. Error & 1,737 & 1,494 & 0,183 & 0,025 & 0,063 \\
Standardized Coefficients & Beta & & $-0,559$ & 1,863 & $-0,061$ & $-0,643$ \\
T & & 1,676 & $-0,119$ & 0,367 & $-0,060$ & $-0,449$ \\
Sig. & & 0,343 & 0,925 & 0,776 & 0,962 & 0,731 \\
Correlations & Zero-order & & 0,703 & 0,746 & $-0,264$ & 0,573 \\
& Partial & & $-0,118$ & 0,344 & $-0,060$ & $-0,410$ \\
Collinearity Statistics & Part & & $-0,071$ & 0,218 & $-0,036$ & $-0,268$ \\
& Tolerance & & 0,016 & 0,014 & 0,346 & 0,173 \\
& VIF & & 62,412 & 72,829 & 2,886 & 5,767 \\
\hline
\end{tabular}

Tahun $=2010$

Dependent Variable: Harga Saham

Sumber : Data diolah

Berdasarkan hasil analisa regresi berganda yang disajikan pada tabel 4 tahun 2010, maka persamaan regresi bergandanya sebagai berikut: 
$\mathrm{Y}=2,910-0,177 \mathrm{X}_{1}+0,067 \mathrm{X}_{2}-$

$0,002 X_{3}-0,028 X_{4}$

Model persamaan regresi berganda tersebut dapat diinterpretasikan sebagai berikut:

a) Return On Assets (ROA) berpengaruh negatif terhadap harga saham perbankan yang listed di Bursa Efek Indonesia tahun 2010 dengan nilai koefisien berpengaruh sebesar - 0,177. Apabila terjadi peningkatan variabel ROA $1 \%$ dengan asumsi variabel lain tetap, maka akan berdampak terjadinya penurunan harga saham sebesar $0,177 \%$. Berarti setiap $1 \%$ kenaikan ROA akan mengakibatkan terjadinya penurunan harga saham sebesar $0,177 \%$.

b) Return On Equity (ROE) berpengaruh positif terhadap harga saham perbankan yang listed di Bursa Efek Indonesia tahun 2010 dengan nilai koefisien berpengaruh sebesar 0,067. Apabila terjadi peningkatan variabel ROE $1 \%$ dengan asumsi variabel lain tetap, maka akan berdampak terjadinya kenaikan harga saham sebesar $0,067 \%$. Berarti setiap $1 \%$ kenaikan ROE akan mengakibatkan terjadinya kenaikan harga saham sebesar $0,067 \%$.

c) Biaya Operasional terhadap Pendapatan Operasional (BOPO) berpengaruh negatif terhadap harga saham perbankan yang listed di Bursa Efek Indonesia tahun 2010 dengan nilai koefisien berpengaruh sebesar -0,002. Apabila terjadi peningkatan variabel BOPO $1 \%$ dengan asumsi variabel lain tetap, maka akan berdampak terjadinya penurunan harga saham sebesar $0,002 \%$. Berarti setiap $1 \%$ kenaikan BOPO akan mengakibatkan terjadinya penurunan harga saham sebesar $0,002 \%$.

d) Net Profit Margin (NPM) berpengaruh negatif terhadap harga saham perbankan yang listed di Bursa Efek Indonesia tahun 2010 dengan nilai koefisien berpengaruh sebesar -0,028. Apabila terjadi peningkatan variabel NPM $1 \%$ dengan asumsi variabel lain tetap, maka akan berdampak terjadinya penurunan harga saham sebesar $0,028 \%$. Berarti setiap $1 \%$ kenaikan NPM akan mengakibatkan terjadinya penurunan harga saham sebesar $0,028 \%$. 
4. Tahun 2011

Tabel 5. Koefisien Tahun 2011

Coefficients $^{\mathrm{a}, \mathrm{b}}$

\begin{tabular}{|ll|c|c|c|c|c|}
\hline \multirow{2}{*}{} & & \multicolumn{5}{|c|}{ Model } \\
\cline { 3 - 7 } & \multicolumn{5}{|c|}{1} \\
\cline { 3 - 7 } & (Constant) & ROA & ROE & BOPO & NPM \\
\hline Unstandardized Coefficients & B & 3,900 & 1,910 & $-0,112$ & $-0,029$ & $-0,052$ \\
& Std. Error & 0,609 & 1,389 & 0,115 & 0,016 & 0,039 \\
Standardized Coefficients & Beta & & 5,056 & $-3,239$ & $-1,316$ & $-1,117$ \\
T & & 6,401 & 1,375 & $-0,975$ & $-1,870$ & $-1,324$ \\
Sig. & & 0,099 & 0,400 & 0,508 & 0,313 & 0,412 \\
Correlations & & 0,516 & 0,558 & $-0,364$ & 0,371 \\
& Zero-order & & 0,809 & $-0,698$ & $-0,882$ & $-0,798$ \\
Collinearity Statistics & Partial & & 0,506 & $-0,358$ & $-0,688$ & $-0,487$ \\
& Part & & 0,010 & 0,012 & 0,273 & 0,190 \\
& Tolerance & & 99,979 & 81,689 & 3,661 & 5,263 \\
\hline
\end{tabular}

a. Tahun $=2011$

b. Dependent Variable: Harga Saham

Sumber: Data diolah

Berdasarkan hasil analisa regresi berganda yang disajikan pada tabel 5 tahun 2011, maka persamaan regresi bergandanya sebagai berikut:

$$
\begin{aligned}
\mathrm{Y}= & 3,900+1,910 \mathrm{X}_{1}-0,112 \mathrm{X}_{2}- \\
& 0,029 \mathrm{X}_{3}-0,052 \mathrm{X}_{4}
\end{aligned}
$$

$\begin{array}{ll}\text { Model persamaan regresi } \\ \text { berganda } & \text { tersebut dapat } \\ \text { diinterpretasikan sebagai berikut: }\end{array}$

a) Return On Assets (ROA) berpengaruh positif terhadap harga saham perbankan yang listed di Bursa Efek Indonesia tahun 2011 dengan nilai koefisien berpengaruh sebesar 1,910. Apabila terjadi peningkatan variabel ROA $1 \%$ dengan asumsi variabel lain tetap, maka akan berdampak terjadinya peningkatan harga saham sebesar $1,910 \%$. Berarti setiap $1 \%$ kenaikan ROA akan mengakibatkan terjadinya kenaikan harga saham sebesar $1,910 \%$.

b) Return On Equity (ROE) berpengaruh negatif terhadap harga saham perbankan yang listed di
Bursa Efek Indonesia tahun 2011 dengan nilai koefisien berpengaruh

sebesar -0,112. Apabila terjadi peningkatan variabel ROE $1 \%$ dengan asumsi variabel lain tetap, maka akan berdampak terjadinya penurunan harga saham sebesar $0,112 \%$. Berarti setiap $1 \%$ kenaikan ROE akan mengakibatkan terjadinya penurunan harga saham sebesar $0,112 \%$.

c) Biaya Operasional terhadap Pendapatan Operasional (BOPO) berpengaruh negatif terhadap harga saham perbankan yang listed di Bursa Efek Indonesia tahun 2011 dengan nilai koefisien berpengaruh sebesar -0,029. Apabila terjadi peningkatan variabel BOPO $1 \%$ dengan asumsi variabel lain tetap, maka akan berdampak terjadinya penurunan harga saham sebesar $0,029 \%$. Berarti setiap $1 \%$ kenaikan BOPO akan mengakibatkan terjadinya 
penurunan harga saham sebesar 0,029\%.

d) Net Profit Margin (NPM) berpengaruh negatif terhadap harga saham perbankan yang listed di Bursa Efek Indonesia tahun 2011 dengan nilai koefisien berpengaruh sebesar -0,052. Apabila terjadi peningkatan variabel NPM $1 \%$ dengan asumsi variabel lain tetap, maka akan berdampak terjadinya penurunan harga saham sebesar $0,052 \%$. Berarti setiap $1 \%$ kenaikan NPM akan mengakibatkan terjadinya penurunan harga saham sebesar $0,052 \%$.

5 Tahun 2012

Tabel 6. Koefisien Tahun 2012

Coefficients $^{\mathrm{a}, \mathrm{b}}$

\begin{tabular}{|ll|c|c|c|c|c|}
\hline \multirow{2}{*}{} & \multicolumn{5}{|c|}{ Model } \\
\cline { 3 - 7 } & \multicolumn{5}{|c|}{1} \\
\cline { 3 - 7 } & (Constant) & ROA & ROE & BOPO & NPM \\
\hline Unstandardized Coefficients & B & 3,031 & 0,267 & $-0,011$ & 0,003 & $-8,804$ \\
& Std. Error & 0,195 & 0,035 & 0,002 & 0,003 & 0,004 \\
Standardized Coefficients & Beta & & 0,761 & $-0,872$ & 0,124 & $-0,002$ \\
T & & 15,511 & 7,642 & $-6,062$ & 0,885 & $-0,024$ \\
Sig. & & 0,041 & 0,083 & 0,104 & 0,539 & 0,984 \\
Correlations & & 0,628 & $-0,654$ & $-0,456$ & 0,323 \\
& Zero-order & & 0,992 & $-0,987$ & 0,663 & $-0,024$ \\
Collinearity Statistics & Partial & & 0,715 & $-0,567$ & 0,083 & $-0,002$ \\
& Part & & 0,883 & 0,423 & 0,447 & 0,885 \\
& Tolerance & & 1,133 & 2,361 & 2,238 & 1,130 \\
\hline
\end{tabular}

a. Tahun $=2012$

b. Dependent Variable: Harga Saham

Sumber : Data diolah

Berdasarkan hasil analisa regresi berganda yang disajikan pada tabel 6 tahun 2012, maka persamaan regresi bergandanya sebagai berikut:

$$
\begin{aligned}
\mathrm{Y}= & 3,031+0,267 \mathrm{X}_{1}-0,011 \mathrm{X}_{2}+ \\
& 0,003 \mathrm{X}_{3}-8,804 \mathrm{X}_{4}
\end{aligned}
$$

Model persamaan regresi berganda tersebut dapat diinterpretasikan sebagai berikut:

a) Return On Assets (ROA) berpengaruh positif terhadap harga saham perbankan yang listed di Bursa Efek Indonesia tahun 2012 dengan nilai koefisien berpengaruh sebesar 0,267. Apabila terjadi peningkatan variabel ROA $1 \%$ dengan asumsi variabel lain tetap, maka akan berdampak terjadinya peningkatan harga saham sebesar
0,267\%. Berarti setiap $1 \%$ kenaikan ROA akan

mengakibatkan terjadinya kenaikan harga saham sebesar 0,267\%.

b) Return On Equity (ROE) berpengaruh negatif terhadap harga saham perbankan yang listed di Bursa Efek Indonesia tahun 2012 dengan nilai koefisien berpengaruh sebesar -0,011. Apabila terjadi peningkatan variabel ROE $1 \%$ dengan asumsi variabel lain tetap, maka akan berdampak terjadinya penurunan harga saham sebesar $0,011 \%$. Berarti setiap $1 \%$ kenaikan ROE akan mengakibatkan terjadinya penurunan harga saham sebesar $0,011 \%$. 
c) Biaya Operasional terhadap Pendapatan Operasional (BOPO) berpengaruh positif terhadap harga saham perbankan yang listed di Bursa Efek Indonesia tahun 2012 dengan nilai koefisien berpengaruh sebesar 0,003. Apabila terjadi peningkatan variabel BOPO $1 \%$ dengan asumsi variabel lain tetap, maka akan berdampak terjadinya kenaikan harga saham sebesar $0,003 \%$. Berarti setiap $1 \%$ kenaikan BOPO akan mengakibatkan terjadinya kenaikan harga saham sebesar $0,003 \%$.

d) Net Profit Margin (NPM) berpengaruh negatif terhadap harga saham perbankan yang listed di Bursa Efek Indonesia tahun 2012 dengan nilai koefisien berpengaruh sebesar -8,804. Apabila terjadi peningkatan variabel NPM $1 \%$ dengan asumsi variabel lain tetap, maka akan berdampak terjadinya penurunan harga saham sebesar $8,804 \%$. Berarti setiap $1 \%$ kenaikan NPM akan mengakibatkan terjadinya penurunan harga saham sebesar $8,804 \%$.

\section{Analisis Masing-Masing Variabel}

a. Variabel Return On Assets/ROA $\left(\mathrm{X}_{1)}\right.$

Pada tabel 2 menunjukkan bahwa variabel independent yang terdiri dari Return On Assets (ROA), Return On Equity (ROE), Biaya Operasional terhadap Pendapatan Operasional (BOPO) dan Net Profit Margin (NPM) memiliki thitung. Dimana ROA thitung sebesar 10,124 dengan tingkat signifikansi sebesar 0,063 yang mana lebih besar dari taraf signifikan yang digunakan $(\alpha=0,05)$ yang berarti bahwa variabel ROA berpengaruh signifikan terhadap harga saham perbankan yang terdaftar di Bursa Efek Indonesia tahun 2008.
Pada tabel 3 menunjukkan ROA dengan thitung sebesar 0,839 dengan tingkat signifikansi sebesar 0,556 yang mana lebih besar dari taraf signifikan yang digunakan $(\alpha=0,05)$ yang berarti bahwa variabel ROA berpengaruh signifikan terhadap harga saham perbankan yang terdaftar di Bursa Efek Indonesia tahun 2009.

Pada tabel 4 menunjukkan ROA dengan thitung sebesar -0,119 dengan tingkat signifikansi sebesar 0,925 yang mana lebih besar dari taraf signifikan yang digunakan $(\alpha=0,05)$ yang berarti bahwa variabel ROA berpengaruh signifikan terhadap harga saham perbankan yang terdaftar di Bursa Efek Indonesia tahun 2010.

Pada tabel 5 menunjukkan ROA dengan $t_{\text {hitung }}$ sebesar 1,375 dengan tingkat signifikansi sebesar 0,400 yang mana lebih besar dari taraf signifikan yang digunakan $(\alpha=0,05)$ yang berarti bahwa variabel ROA berpengaruh signifikan terhadap harga saham perbankan yang terdaftar di Bursa Efek Indonesia tahun 2011.

Pada tabel 6 menunjukkan ROA dengan $t_{\text {hitung sebesar 7,642 dengan }}$ tingkat signifikansi sebesar 0,083 yang mana lebih besar dari taraf signifikan yang digunakan $(\alpha=0,05)$ yang berarti bahwa variabel ROA berpengaruh signifikan terhadap harga saham perbankan yang terdaftar di Bursa Efek Indonesia tahun 2012.

Hasil ini mengindikasikan bahwa Return On Assets (ROA) dapat dipertimbangkan oleh manajemen dalam mempengaruhi harga saham, sehingga para pemegang saham penting untuk mempertimbangkan ROA dalam melihat kestabilan harga saham. Dengan demikian hipotesis yang mengatakan variabel ROA berpengaruh signifikan terhadap harga saham perbankan yang terdaftar di 
Bursa Efek Indonesia tahun 2008 2012 diterima (tolak $\mathrm{H}_{0}$ ).

\section{b. Variabel Return On Equity/ROE $\left(\mathrm{X}_{2}\right)$}

Pada tabel 2 menunjukkan bahwa variabel independent Return On Equity (ROE) dengan thitung sebesar 8,643 dengan tingkat signifikansi sebesar 0,073 yang mana lebih besar dari taraf signifikan yang digunakan $(\alpha$ $=0,05)$ yang berarti bahwa variabel ROE berpengaruh signifikan terhadap harga saham perbankan yang terdaftar di Bursa Efek Indonesia tahun 2008.

Pada tabel 3 menunjukkan ROE dengan $t_{\text {hitung }}$ sebesar $-0,633$ dengan tingkat signifikansi sebesar 0,641 yang mana lebih besar dari taraf signifikan yang digunakan $(\alpha=0,05)$ yang berarti bahwa variabel ROE berpengaruh signifikan terhadap harga saham perbankan yang terdaftar di Bursa Efek Indonesia tahun 2009.

Pada tabel 4 menunjukkan ROE dengan $t_{\text {hitung }}$ sebesar 0,367 dengan tingkat signifikansi sebesar 0,776 yang mana lebih besar dari taraf signifikan yang digunakan $(\alpha=0,05)$ yang berarti bahwa variabel ROE berpengaruh signifikan terhadap harga saham perbankan yang terdaftar di Bursa Efek Indonesia tahun 2010.

Pada tabel 5 menunjukkan ROE dengan thitung sebesar -0, 975 dengan tingkat signifikansi sebesar 0,508 yang mana lebih besar dari taraf signifikan yang digunakan $(\alpha=0,05)$ yang berarti bahwa variabel ROE berpengaruh signifikan terhadap harga saham perbankan yang terdaftar di Bursa Efek Indonesia tahun 2011.

Pada tabel 6 menunjukkan ROE dengan thitung sebesar -6,062 dengan tingkat signifikansi sebesar 0,104 yang mana lebih besar dari taraf signifikan yang digunakan $(\alpha=0,05)$ yang berarti bahwa variabel ROE berpengaruh signifikan terhadap harga saham perbankan yang terdaftar di Bursa Efek Indonesia tahun 2012.

Hasil ini mengindikasikan bahwa ROE dapat menjadi faktor utama dalam menentukan pergerakan harga saham, sehingga investor perlu mempertimbangkan ROE dalam melakukan investasi. Dengan demikian hipotesis yang mengatakan variabel ROE berpengaruh signifikan terhadap harga saham perbankan yang terdaftar di Bursa Efek Indonesia dari tahun 2008 - 2012 diterima (tolak $\mathrm{H}_{0}$ ).

c. Variabel Biaya Operasional terhadap Pendapatan Operasional/BOPO $\left(\mathrm{X}_{3}\right)$

Tabel 2 menunjukkan bahwa variabel independent Biaya Operasional terhadap Pendapatan Operasional (BOPO) dengan thitung sebesar -10,487 dengan tingkat signifikansi sebesar 0,061 yang mana lebih besar dari taraf signifikan yang digunakan $(\alpha=0,05)$ yang berarti bahwa variabel BOPO berpengaruh signifikan terhadap harga saham perbankan yang terdaftar di Bursa Efek Indonesia tahun 2008.

Tabel 3 menunjukkan BOPO dengan $t_{\text {hitung }}$ sebesar $-1,404$ dengan tingkat signifikansi sebesar 0,394 yang mana lebih besar dari taraf signifikan yang digunakan $(\alpha=0,05)$ yang berarti bahwa variabel BOPO berpengaruh signifikan terhadap harga saham perbankan yang terdaftar di Bursa Efek Indonesia tahun 2009.

Tabel 4 menunjukkan BOPO dengan $t_{\text {hitung }}$ sebesar $-0,060$ dengan tingkat signifikansi sebesar 0,962 yang mana lebih besar dari taraf signifikan yang digunakan $(\alpha=0,05)$ yang berarti bahwa variabel BOPO berpengaruh signifikan terhadap harga saham perbankan yang terdaftar di Bursa Efek Indonesia tahun 2010. 
Tabel 5 menunjukkan BOPO dengan $t_{\text {hitung }}$ sebesar $-1,870$ dengan tingkat signifikansi sebesar 0,313 yang mana lebih besar dari taraf signifikan yang digunakan $(\alpha=0,05)$ yang berarti bahwa variabel BOPO berpengaruh signifikan terhadap harga saham perbankan yang terdaftar di Bursa Efek Indonesia tahun 2011.

Tabel 6 menunjukkan BOPO dengan thitung sebesar 0,885 dengan tingkat signifikansi sebesar 0,539 yang mana lebih besar dari taraf signifikan yang digunakan $(\alpha=0,05)$ yang berarti bahwa variabel BOPO berpengaruh signifikan terhadap harga saham perbankan yang terdaftar di Bursa Efek Indonesia tahun 2012.

Berdasarkan hasil analisis diatas BOPO dapat dijadikan acuan bagi pergerakan harga saham yang akan mempengaruhi investor dalam mengambil keputusan investasi. Dengan demikian hipotesis yang mengatakan variabel BOPO berpengaruh signifikan terhadap harga saham perbankan yang terdaftar di Bursa Efek Indonesia dari tahun 2008 - 2012 diterima (tolak $\mathrm{H}_{0}$ ).

\section{d. Variabel Net Profit Margin/ NPM $\left(\mathrm{X}_{4}\right)$}

Tabel 2 menunjukkan bahwa variabel independent Net Profit Margin (NPM) dengan thitung sebesar 9,034 dengan tingkat signifikansi sebesar 0,070 yang mana lebih besar dari taraf signifikan yang digunakan $(\alpha$ $=0,05$ ) yang berarti bahwa variabel NPM berpengaruh signifikan terhadap harga saham perbankan yang terdaftar di Bursa Efek Indonesia tahun 2008.

Tabel 3 menunjukkan NPM dengan thitung sebesar 0,478 dengan tingkat signifikansi sebesar 0,716 yang mana lebih besar dari taraf signifikan yang digunakan $(\alpha=0,05)$ yang berarti bahwa variabel NPM berpengaruh signifikan terhadap harga saham perbankan yang terdaftar di Bursa Efek Indonesia tahun 2009.

Tabel 4 menunjukkan NPM dengan $t_{\text {hitung }}$ sebesar -0,449 dengan tingkat signifikansi sebesar 0,731 yang mana lebih besar dari taraf signifikan yang digunakan $(\alpha=0,05)$ yang berarti bahwa variabel NPM berpengaruh signifikan terhadap harga saham perbankan yang terdaftar di Bursa Efek Indonesia tahun 2010.

Tabel 5 menunjukkan NPM dengan $t_{\text {hitung }}$ sebesar $-1,324$ dengan tingkat signifikansi sebesar 0,412 yang mana lebih besar dari taraf signifikan yang digunakan $(\alpha=0,05)$ yang berarti bahwa variabel NPM berpengaruh signifikan terhadap harga saham perbankan yang terdaftar di Bursa Efek Indonesia tahun 2011.

Tabel 6 menunjukkan NPM dengan $t_{\text {hitung }}$ sebesar $-0,024$ dengan tingkat signifikansi sebesar 0,984 yang mana lebih besar dari taraf signifikan yang digunakan $(\alpha=0,05)$ yang berarti bahwa variabel NPM berpengaruh signifikan terhadap harga saham perbankan yang terdaftar di Bursa Efek Indonesia tahun 2012.

Hasil ini mengindikasikan bahwa pergerakan harga saham dipengaruhi oleh Net Profit Margin, sehingga investor perlu menjadikan NPM sebagai acuan dalam mengambil keputusan investasi. Dengan demikian hipotesis yang mengatakan variabel Net Profit Margin berpengaruh signifikan terhadap harga saham perbankan yang terdaftar di Bursa Efek Indonesia dari tahun 2008 - 2012 diterima (tolak $\mathrm{H}_{0}$ ).

\section{Uji F (Simultan)}

Hipotesis pengaruh variabel independen (Return On Assets, Return On Equity, Biaya Operasional terhadap Pendapatan Operasional dan Net Profit Margin) terhadap variabel dependen 
(harga saham) berpengaruh sangat kuat. Variabel dependen (harga saham) dapat dijelaskan oleh variabel independen yang ada yaitu Return On Assets, Return On Equity, Biaya Operasional terhadap Pendapatan Operasional dan Net Profit Margin dengan melihat $R$ square (karena variabel penelitian lebih dari dua variabel) tahun 2008 sebesar 99,5\% sedangkan sisanya $0,5 \%$ dipengaruhi oleh variabel lain yang tidak dibahas dalam penelitian ini. Tahun 2009 dipengaruhi sebesar 78,6 \% sedangkan sisanya $21,4 \%$ dipengaruhi oleh variabel lain yang tidak dibahas dalam penelitian ini, tahun 2010 dipengaruhi sebesar $64,5 \%$ sedangkan sisanya 35,5
$\%$ dipengaruhi oleh variabel lain yang tidak dibahas dalam penelitian ini, tahun 2011 dipengaruhi sebesar 86,5\% sedangkan sisanya $13,5 \%$ dipengaruhi oleh variabel lain yang tidak dibahas dalam penelitian ini dan tahun 2012 dipengaruhi sebesar 99,1\% sedangkan sisanya $0,9 \%$ dipengaruhi oleh variabel lain yang tidak dibahas dalam penelitian ini. Jadi secara keseluruhan atau bersama variabel independen berpengaruh signifikan terhadap variabel dependen. Nilai $\mathrm{R}$ square yang diperoleh dari hasil pengolahan data dengan menggunakan program SPSS versi 16 pada tabel 7 dibawah ini:

Tabel 7.

Model Summary Tahun 2008 - 2012

\begin{tabular}{|c|c|c|c|c|c|}
\hline Tahun & Model & $\mathrm{R}$ & $\mathrm{R}$ Square & $\begin{array}{c}\text { Adjust R } \\
\text { Square }\end{array}$ & $\begin{array}{c}\text { Std. Error of } \\
\text { the Estimate }\end{array}$ \\
\hline 2008 & 1 & $0,997^{\mathrm{a}}$ & 0,995 & 0,975 & 0,06311 \\
\hline 2009 & 1 & $0,887^{\mathrm{a}}$ & 0,786 & $-0,069$ & 0,37816 \\
\hline 2010 & 1 & $0,803^{\mathrm{a}}$ & 0,645 & $-0,773$ & 0,54388 \\
\hline 2011 & 1 & $0,930^{\mathrm{a}}$ & 0,865 & 0,324 & 0,28950 \\
\hline 2012 & 1 & $0,996^{\mathrm{a}}$ & 0,991 & 0,956 & 0,06178 \\
\hline
\end{tabular}

Sumber: Data diolah

Untuk melihat tingkat kepercayaan, selanjutnya atau uji $\mathrm{F}$ yang dapat dilihat pada dilakukan uji signifikan, simultan tabel 8 berikut ini:

Tabel 8.

ANOVA $^{\text {b,c }}$ Tahun 2008

\begin{tabular}{|c|c|c|c|c|c|c|}
\hline \multicolumn{2}{|c|}{ Model } & Sum of Squares & Df & Mean Square & $\mathrm{F}$ & Sig. \\
\hline \multirow[t]{3}{*}{1} & Regression & 0,782 & 4 & 0,195 & 49,072 & $0,107^{\mathrm{a}}$ \\
\hline & Residual & 0,004 & 1 & 0,004 & & \\
\hline & Total & 0,786 & 5 & & & \\
\hline
\end{tabular}

a. Predictors: (Constant), NPM, BOPO, ROE, ROA

b. Dependent Variable: Harga Saham

Sumber: Data diolah

Secara simultan hipotesis yang menyatakan bahwa pengaruh variabel independen (ROA, ROE, BOPO dan NPM) terhadap variabel dependen (harga saham) pada perbankan yang terdaftar di Bursa Efek Indonesia tahun 2008 dapat diterima. Indikator signifikansi parameter adjusted $\mathrm{R}$ square signifikan atau tidak dapat dilakukan pengujian dengan bantuan 
alat uji statistik metode Fisher (uji F) dengan tingkat keyakinan sebesar 95 $\%$. Kriteria pengujian yang digunakan adalah apabila $F_{\text {hitung }}>F_{\text {tabel }}$ maka hipotesis awal ditolak.

Dari tabel 8 diperoleh nilai $F_{\text {hitung }}$ sebesar 49,072 sedangkan $F_{\text {tabel }}$ sebesar 2,759 pada tingkat kepercayaan $95 \%(\alpha=0,05)$. Hal ini berarti bahwa nilai $F_{\text {hitung }}>F_{\text {tabel }}$ dengan tingkat signifikansi sebesar
0,107 yang lebih besar dari nilai alpha $(0,05)$. Hal ini memberikan arti bahwa variabel-variabel independen ROA, ROE, BOPO dan NPM secara bersama-sama berpengaruh signifikan terhadap harga saham. Dengan demikian hipotesis yang menyatakan bahwa varibel ROA, ROE, BOPO dan NPM secara bersama-sama berpengaruh signifikan terhadap harga saham diterima.

Tabel 9.

ANOVA ${ }^{\text {b,c }}$ Tahun 2009

\begin{tabular}{|ll|c|c|c|c|c|}
\hline Model & & Sum of Squares & Df & Mean Square & F & Sig. \\
\hline 1 & Regression & 0,526 & 4 & 0,131 & 0,919 & $0,644^{\mathrm{a}}$ \\
& Residual & 0,143 & 1 & 0,143 & & \\
& Total & 0,669 & 5 & & & \\
\hline
\end{tabular}

a. Predictors: (Constant), NPM, BOPO, ROA, ROE

b. Dependent Variable: Harga Saham

Sumber: Pengolahan Data

Secara simultan hipotesis yang menyatakan bahwa pengaruh variabel independen (ROA, ROE, BOPO dan NPM) terhadap variabel dependen (harga saham) pada perbankan yang terdaftar di Bursa Efek Indonesia tahun 2009 dapat diterima. Indikator signifikansi parameter adjusted $R$ square signifikan atau tidak dapat dilakukan pengujian dengan bantuan alat uji statistik metode Fisher (uji F) dengan tingkat keyakinan sebesar $95 \%$. Kriteria pengujian yang digunakan adalah apabila $F_{\text {hitung }}>F_{\text {tabel }}$ maka hipotesis awal ditolak.

Dari tabel 9 diperoleh nilai $F_{\text {hitung }}$ sebesar 0,919 sedangkan $F_{\text {tabel }}$ sebesar 2,759 pada tingkat kepercayaan $95 \%(\alpha=0,05)$. Hal ini berarti bahwa nilai $F_{\text {hitung }}<F_{\text {tabel }}$ dengan tingkat signifikansi sebesar 0,644 yang lebih besar dari nilai alpha $(0,05)$. Hal ini memberikan arti bahwa variabel- variabel independen ROA, ROE, BOPO dan NPM secara bersama-sama tidak berpengaruh signifikan terhadap harga saham.

Dengan demikian hipotesis yang menyatakan bahwa variabel ROA, ROE, BOPO dan NPM secara bersama-sama berpengaruh signifikan terhadap harga saham pada tahun 2009 ditolak.

Tabel 10

ANOVA $^{\mathrm{b}, \mathrm{c}}$ Tahun $=\mathbf{2 0 1 0}$ 


\begin{tabular}{|ll|c|c|c|c|c|}
\hline \multicolumn{1}{|l|}{ Model } & Sum of Squares & Df & Mean Square & F & Sig. \\
\hline $1 \quad$ Regression & 0,538 & 4 & 0,135 & 0,455 & $0,788^{\mathrm{a}}$ \\
Residual & 0,296 & 1 & 0,296 & & \\
Total & 0,834 & 5 & & & \\
\hline
\end{tabular}

a. Predictors: (Constant), NPM, BOPO, ROA, ROE

b. Dependent Variable: Harga Saham

Sumber : Data diolah

Secara simultan hipotesis yang menyatakan bahwa pengaruh variabel independen (ROA, ROE, BOPO dan NPM) terhadap variabel dependen (harga saham) pada perbankan yang terdaftar di Bursa Efek Indonesia tahun 2010 dapat diterima. Indikator signifikansi parameter adjusted $\mathrm{R}$ square signifikan atau tidak dapat dilakukan pengujian dengan bantuan alat uji statistik metode Fisher (Uji F) dengan tingkat keyakinan sebesar 95\%. Kriteria pengujian yang digunakan adalah apabila $F_{\text {hitung }}>F_{\text {tabel }}$ maka, hipotesis awal ditolak.

Dari tabel 10. diperoleh nilai $F_{\text {hitung }}$ sebesar 0,455 sedangkan $F_{\text {tabel }}$ sebesar 2,759 pada tingkat kepercayaan 95\% $(\alpha=0,05)$. Hal ini berarti bahwa nilai $\mathrm{F}_{\text {hitung }}<$ $\mathrm{F}_{\text {tabel }}$ dengan tingkat signifikansi sebesar 0,788 yang lebih besar dari nilai alpha $(0,05)$. Hal ini memberikan arti bahwa variabel-variabel independen ROA, ROE, BOPO dan NPM secara bersama-sama tidak berpengaruh signifikan terhadap harga saham.

Dengan demikian hipotesis yang menyatakan bahwa variabel ROA, ROE, BOPO dan NPM secara bersama-sama berpengaruh signifikan terhadap harga saham pada tahun 2010 ditolak.

Tabel 11.

ANOVA $^{\mathrm{b}, \mathrm{c}}$ Tahun 2011

\begin{tabular}{|ll|c|c|c|c|c|}
\hline Model & & Sum of Squares & Df & Mean Square & F & Sig. \\
\hline 1 & Regression & 0,536 & 4 & 0,134 & 1,599 & $0,527^{\text {a }}$ \\
& Residual & 0,084 & 1 & 0,084 & & \\
& Total & 0,620 & 5 & & & \\
\hline
\end{tabular}

a. Predictors: (Constant), NPM, BOPO, ROE, ROA

b. Dependent Variable: Harga Saham

Sumber: Pengolahan Data

Secara simultan hipotesis yang menyatakan bahwa pengaruh variabel independen (ROA, ROE, BOPO dan NPM) terhadap variabel dependen (harga saham) pada perbankan yang terdaftar di Bursa Efek Indonesia tahun 2011 dapat diterima. Indikator signifikansi parameter adjusted $\mathrm{R}$ square signifikan atau tidak dapat dilakukan pengujian dengan bantuan alat uji statistik metode Fisher (uji F) dengan tingkat keyakinan sebesar $95 \%$. Kriteria pengujian yang digunakan adalah apabila $F_{\text {hitung }}>F_{\text {tabel }}$ maka hipotesis awal ditolak.
Dari tabel 11. diperoleh nilai $F_{\text {hitung }}$ sebesar 1,599 sedangkan $F_{\text {tabel }}$ sebesar 2,759 pada tingkat kepercayaan $95 \%(\alpha=0,05)$. Hal ini berarti bahwa nilai $F_{\text {hitung }}<F_{\text {tabel }}$ dengan tingkat signifikansi sebesar 0,527 yang lebih besar dari nilai alpha $(0,05)$. Hal ini memberikan arti bahwa variabel-variabel independen ROA, ROE, BOPO dan NPM secara bersama-sama tidak berpengaruh signifikan terhadap harga saham.

Dengan demikian hipotesis yang menyatakan bahwa variabel 
ROA, ROE, BOPO dan NPM secara bersama-sama berpengaruh signifikan terhadap harga saham pada tahun 2011 ditolak.

Tabel 12.

ANOVA $^{\text {b,c }}$ Tahun 2012

\begin{tabular}{|ll|c|c|c|c|c|}
\hline Model & & Sum of Squares & $\mathrm{df}$ & Mean Square & $\mathrm{F}$ & Sig. \\
\hline 1 & Regression & 0,432 & 4 & 0,108 & 28,292 & $0,140^{\mathrm{a}}$ \\
& Residual & 0,004 & 1 & 0,004 & & \\
& Total & 0,436 & 5 & & & \\
\hline
\end{tabular}

a. Predictors: (Constant), NPM, BOPO, ROA, ROE

b. Dependent Variable: Harga Saham

Sumber: Pengolahan Data

Secara simultan hipotesis yang menyatakan bahwa pengaruh variabel independen (ROA, ROE, BOPO dan NPM) terhadap variabel dependen (harga saham) pada perbankan yang terdaftar di Bursa Efek Indonesia tahun 2012 dapat diterima. Indikator signifikansi parameter adjusted $\mathrm{R}$ square signifikan atau tidak dapat dilakukan pengujian dengan bantuan alat uji statistik metode Fisher (uji F) dengan tingkat keyakinan sebesar $95 \%$. Kriteria pengujian yang digunakan adalah apabila $F_{\text {hitung }}>F_{\text {tabel }}$ maka hipotesis awal ditolak.

Dari tabel 12. diperoleh nilai $F_{\text {hitung }}$ sebesar 28,292 sedangkan $F_{\text {tabel }}$ sebesar 2,759 pada tingkat kepercayaan $95 \%(\alpha=0,05)$. Hal ini berarti bahwa nilai $F_{\text {hitung }}>F_{\text {tabel }}$ dengan tingkat signifikansi sebesar 0,140 yang lebih besar dari nilai alpha $(0,05)$. Hal ini memberikan arti bahwa variabelvariabel independen ROA, ROE, BOPO dan NPM secara bersama-sama berpengaruh signifikan terhadap harga saham.

Dengan demikian hipotesis yang menyatakan bahwa variabel ROA, ROE, BOPO dan NPM secara bersamasama berpengaruh signifikan terhadap harga saham pada tahun 2012 diterima.

\section{SIMPULAN DAN IMPLIKASI PENELITIAN}

\section{Simpulan}

Berdasarkan hasil penelitian, dapat disimpulkan sebagai berikut:

1) Pengujian terhadap hipotesis pertama yang menggunakan variabel independen Return On Asset (ROA) pada tahun 2008 diperoleh hasil signifikansi sebesar 0,063 . Nilai signifikansi 0,063 berada diatas nilai alpha $(0,05)$, ini berarti $\mathrm{H}_{0}$ pada tahun 2008 ditolak dan dapat disimpulkan bahwa ROA berpengaruh signifikan terhadap harga saham. Pada tahun 2009 diperoleh hasil signifikansi sebesar 0,556 . Nilai signifikansi 0,556 berada diatas nilai alpha $(0,05)$, ini berarti $\mathrm{H}_{0}$ pada tahun 2007 ditolak dan dapat disimpulkan bahwa ROA berpengaruh signifikan terhadap harga saham. Pada tahun 2010 diperoleh hasil signifikansi sebesar 0,925 . Nilai signifikansi 0,925 berada diatas nilai alpha $(0,05)$, ini berarti $\mathrm{H}_{0}$ pada tahun 2010 ditolak dan dapat disimpulkan bahwa ROA berpengaruh signifikan terhadap harga saham. Pada tahun 2011 diperoleh hasil signifikansi sebesar 0,400 . Nilai signifikansi 0,400 berada diatas nilai alpha $(0,05)$, ini berarti $\mathrm{H}_{0}$ pada tahun 2011 ditolak dan dapat disimpulkan bahwa ROA berpengaruh signifikan terhadap harga saham. Pada tahun 2012 
diperoleh hasil signifikansi sebesar 0,083. Nilai signifikansi 0,083 berada diatas nilai alpha $(0,05)$, ini berarti $\mathrm{H}_{0}$ pada tahun 2012 ditolak dan dapat disimpulkan bahwa ROA berpengaruh signifikan terhadap harga saham.

2) Pengujian terhadap hipotesis kedua yang menggunakan variabel independen Return On Equity (ROE) pada tahun 2008 diperoleh hasil signifikansi sebesar 0,073. Nilai signifikansi 0,073 berada diatas nilai alpha $(0,05)$, ini berarti $\mathrm{H}_{0}$ pada tahun 2008 ditolak, dan dapat disimpulkan bahwa ROE berpengaruh signifikan terhadap harga saham. Pada tahun 2009 diperoleh hasil signifikansi sebesar 0,641 . Nilai signifikansi 0,641 berada diatas nilai alpha $(0,05)$, ini berarti $\mathrm{H}_{0}$ pada tahun 2009 ditolak dan dapat disimpulkan bahwa ROE berpengaruh signifikan terhadap harga saham. Pada tahun 2010 diperoleh hasil signifikansi sebesar 0,776 . Nilai signifikansi 0,776 berada diatas nilai alpha $(0,05)$, ini berarti $\mathrm{H}_{0}$ pada tahun 2010 ditolak dan dapat disimpulkan bahwa ROE berpengaruh signifikan terhadap harga saham. Pada tahun 2011 diperoleh hasil signifikansi sebesar 0,508 . Nilai signifikansi 0,508 berada diatas nilai alpha $(0,05)$, ini berarti $\mathrm{H}_{0}$ pada tahun 2011 ditolak dan dapat disimpulkan bahwa ROE berpengaruh signifikan terhadap harga saham. Pada tahun 2012 diperoleh hasil signifikansi sebesar 0,104 . Nilai signifikansi 0,104 berada diatas nilai alpha $(0,05)$, ini berarti $\mathrm{H}_{0}$ pada tahun 2012 ditolak dan dapat disimpulkan bahwa ROE berpengaruh signifikan terhadap harga saham.
3) Pengujian terhadap hipotesis ketiga yang menggunakan variabel independen Biaya Operasional terhadap Pendapatan Operasional (BOPO) pada tahun 2008 diperoleh hasil signifikansi sebesar 0,061. Nilai signifikansi 0,061 berada diatas nilai alpha $(0,05)$, ini berarti $\mathrm{H}_{0}$ pada tahun 2008 ditolak dan dapat disimpulkan bahwa BOPO berpengaruh signifikan terhadap harga saham. Pada tahun 2009 diperoleh hasil signifikansi sebesar 0,394 . Nilai signifikansi 0,394 berada diatas nilai alpha $(0,05)$, ini berarti $\mathrm{H}_{0}$ pada tahun 2009 ditolak dan dapat disimpulkan bahwa BOPO berpengaruh signifikan terhadap harga saham. Pada tahun 2010 diperoleh hasil signifikansi sebesar 0,962. Nilai signifikansi 0,962 berada diatas nilai alpha $(0,05)$, ini berarti $\mathrm{H}_{0}$ pada tahun 2010 ditolak dan dapat disimpulkan bahwa BOPO berpengaruh signifikan terhadap harga saham. Pada tahun 2011 diperoleh hasil signifikansi sebesar 0,313. Nilai signifikansi 0,313 berada diatas nilai alpha $(0,05)$, ini berarti $\mathrm{H}_{0}$ pada tahun 2011 ditolak dan dapat disimpulkan bahwa BOPO berpengaruh signifikan terhadap harga saham. Pada tahun 2012 diperoleh hasil signifikansi sebesar 0,539 . Nilai signifikansi 0,539 berada diatas nilai alpha $(0,05)$, ini berarti $\mathrm{H}_{0}$ pada tahun 2012 ditolak dan dapat disimpulkan bahwa BOPO berpengaruh signifikan terhadap harga saham.

4) Pengujian terhadap hipotesis keempat yang menggunakan variabel independen Net Profit Margin (NPM) pada tahun 2008 diperoleh hasil signifikansi sebesar 0,070. Nilai signifikansi 0,070 
berada diatas nilai alpha $(0,05)$, ini berarti $\mathrm{H}_{0}$ pada tahun 2008 ditolak dan dapat disimpulkan bahwa NPM berpengaruh signifikan terhadap harga saham. Pada tahun 2009 diperoleh hasil signifikansi sebesar 0,716. Nilai signifikansi 0,716 berada diatas nilai alpha $(0,05)$, ini berarti $\mathrm{H}_{0}$ pada tahun 2009 ditolak dan dapat disimpulkan bahwa NPM berpengaruh signifikan terhadap harga saham. Pada tahun 2010 diperoleh hasil signifikansi sebesar 0,731. Nilai signifikansi 0,731 berada diatas nilai alpha $(0,05)$, ini berarti $\mathrm{H}_{0}$ pada tahun 2010 ditolak dan dapat disimpulkan bahwa NPM berpengaruh signifikan terhadap harga saham. Pada tahun 2011 diperoleh hasil signifikansi sebesar 0,412 . Nilai signifikansi 0,412 berada diatas nilai alpha $(0,05)$, ini berarti $\mathrm{H}_{0}$ pada tahun 2011 ditolak dan dapat disimpulkan bahwa NPM berpengaruh signifikan terhadap harga saham. Pada tahun 2012 diperoleh hasil signifikansi sebesar 0,984 . Nilai signifikansi 0,984 berada diatas nilai alpha $(0,05)$, ini berarti $\mathrm{H}_{0}$ pada tahun 2012 ditolak dan dapat disimpulkan bahwa NPM berpengaruh signifikan terhadap harga saham.

Hipotesis yang terakhir pengujian secara simultan atau bersama dimana variabel independen yaitu ROA, ROE, BOPO dan NPM secara bersama-sama disimpulkan bahwa ditahun 2008 memiliki pengaruh yang signifikan terhadap variabel dependen harga saham. Indikasi ini dapat terlihat dari nilai signifikan 0,107 yang berada diatas nilai alpha $(0,05)$. Tahun 2009 disimpulkan dengan nilai signifikansi sebesar 0,644 berada diatas nilai alpha $(0,05)$, dimana secara simultan variabel independen tidak berpengaruh signifikan terhadap harga saham. Tahun 2010 disimpulkan dengan nilai signifikansi sebesar 0,788 berada diatas nilai alpha $(0,05)$, dimana secara simultan variabel independen tidak berpengaruh signifikan terhadap harga saham. Tahun 2011 disimpulkan dengan nilai signifikansi sebesar 0,527 berada diatas nilai alpha $(0,05)$, dimana secara simultan variabel independen tidak berpengaruh signifikan terhadap harga saham. Sedangkan pada tahun 2012 secara simultan disimpulkan variabel independen berpengaruh signifikan terhadap harga saham dengan nilai signifikansi berada diatas alpha $(0,05)$ yaitu sebesar 0,140 .

\section{DAFTAR PUSTAKA}

Abdullah, Faisal. 2001. Dasar dasar manajemen keuangan. Malang: UMM Press.

Alghifari. 2002. Analisis Regresi Teori, Kasus, dan Solusi, Edisi kedua. Yogyakarta: BPFE.

Arikunto, Suharsimi, 2006. Prosedur Penelitian Suatu Pendekatan Praktik, Edisi VI. Jakarta: PT.Rineka Cipta.

Astika, Hellmy. 2004. "Analisa kinerja Bank sebelum dan sesudah go public di Bursa Efek Indonesia (Study pada Bank Central Asia. Tbk)" Skripsi yang tidak diterbitkan. FE-Universitas Brawijaya Malang.

Bursa Efek Indonesia, PT. 2011. IDX Statistik. Jakarta: Diakses tanggal 18 April 2011. dari http://www.idx.co.id.

Dendawijaya, Lukman. 2003. Lima Tahun Penyehatan Perbankan Nasional 1998-2003. Bogor selatan: Ghalia Indonesia.

Fahmi, Irham. 2006. Analisis Investasi dalam perspektif Ekonomi dan Politik. Bandung: PT. Refika Aditama. 
Halim, Abdul. 2005. Analisis Investasi. Jakarta: Salemba Empat.

Husnan, Suad, dkk. 1993. Dasar-Dasar Manajemen Perbankan. Yogyakarta: YKPN.

Indriartoro, Nur dan Bambang Supomo. 1999. Metodologi Penelitian Bisnis untuk Akuntansi dan Manajemen, Edisi Pertama. Yogyakarta: BPFE.

Kashmir. 1999. Bank dan Lembaga Keuangan Lainnya, Edisi Keenam. Jakarta: PT. RajaGrafindo Persada. 2002. Dasar Dasar Perbankan. Jakarta: PT. Raja Grafindo Persada.

2005. Manajemen

Perbankan. $2005 . \quad$ Manajemen
Ghaliia Indonesia.

Kuncoro, Mudrajad. 2007. Metode Kuantitatif Teori dan Aplikasi untuk Bisnis dan Ekonomi, Edisi Ketiga. Yogyakarta: Unit Penerbit dan Percetakan (UPP) STIM YKP.

Kurniawati, Dyah. 2009. "Analisis Rasio Keuangan dengan Menggunakan Rasio Rentabilitas dan Solvabilitas pada PT. Bank Rakyat Indonesia (persero) .Tbk." Skripsi tidak Diterbitkan. FEUniversitas Brawijaya. Malang.

Munawir. 2002. Analisis Laporan Keuangan. Jakarta.

Prahesti Liling Ari. 2009. "Analisis pengaruh kinerja keuangan yang diukur dengan ROI, ROE, OCF dan EVA terhadap Rate Of Return (Studi pada perusahaan Otomotif yang terdaftar di BEI)." Skripsi yang tidak diterbitkan. FE Universitas Brawijaya. Malang

Rojihah, Nur. 2005. "Pengaruh kinerja perusahaan perbankan terhadap harga saham setelah Initial Public Offering." Skripsi yang tidak diterbitkan. FE UIN Malang.
Santosa, Purbayu Budi dan Hamdani, Muliarwan. 2007. Statistika Deskriptif dalam Bidang Ekonomi dan Niaga. Jakarta: Erlangga.

Santoso, Singgih. 2000. Buku latihan SPSS Statistik Parametrik. Jakarta: PT. Elek Komputindo Kelompok Gramedia.

Sugiyono. 1999. Metode Penelitian Bisnis. Bandung: Alfabeta.

Triandaru, Sigit, dan Budisantoso, Totok. 2006. Bank dan lembaga Keuangan Lainnya, Edisi kedua. Yogyakarta: Salemba Empat.

Tandelilin, Eduardus. 2001. Portofolio dan Investasi (Teori dan Aplikasi).Yogyakarta: Kanisius.

Wahidmurni. 2008. Cara mudah menulis Proposal dan Laporan Penelitian Lapangan Pendekatan Kualitatif dan Kuantitatif (Skripsi, Tesis dan Disertasi). IKIP Malang: UM Press 